\title{
Plant Density and Genotype Evaluation for High Density Planting System of Cotton under Rainfed Condition
}

\author{
A. D. Pandagale ${ }^{1}$, K. S. Baig ${ }^{1 *}$, S. S. Rathod $^{1}$ and T. B. Namade $^{2}$ \\ ${ }^{1}$ Cotton Research Station, Nanded (M.S.), India \\ ${ }^{2}$ College of Agriculture, Wadala, Dist. Solapur, India \\ *Corresponding author
}

Keywords

High density planting system,

Cotton, Genotype,

Spacing, Plant density, Economics

Article Info

Accepted:

12 August 2020

Available Online:

10 September 2020

\begin{abstract}
A B S T R A C T
A field experiment was conducted to evaluate optimum plant density and suitable $G$. hirsutum cotton genotype for high density planting system under rainfed condition. Plant growth parameters, seed cotton yield and economics of cotton genotypes under various high planting densities were studied during kharif, 2013-14 to 2015-16 on medium soil. Increase in plant density has reduced monopodial branches plant ${ }^{-1}$ whereas, number of bolls plant were increased with increase in density. The plant density of 1.66 lakh plants $\mathrm{ha}^{-1}$ (spacing $60 \times 10 \mathrm{~cm}$ ) resulted in higher seed cotton yield $\left(1705 \mathrm{~kg} \mathrm{ha}^{-1}\right.$ ) and net monetary returns (Rs. 40,496/- ha ${ }^{-1}$ ). The hirsutum cotton genotypes NH 615, NH 635 and Suraj were found suitable for high density planting system as exhibited greater number of bolls plant ${ }^{-1}$, yield plant $^{-1}$, seed cotton yield ha ${ }^{-1}\left(1742 \mathrm{~kg} \mathrm{ha}^{-1}\right.$ and $1683 \mathrm{~kg} \mathrm{ha}^{-1}$, respectively) and monetary returns. The genotype Suraj was found to be high ginner (37.40 per cent) followed by NH 615 (37.35 per cent).
\end{abstract}

\section{Introduction}

Cotton is one of the principal commercial crops. It plays a vital role in Indian economy. It provides employment on farming, processing and marketing sectors. It provides basic raw material to ginning - pressing, textile industry and export - import of yarn and fabrics. India ranks first in area (122 lakh ha) and production (380 lakh bales) on the globe with $38.13 \%$ area and $26.75 \%$ production during 2019-20 (Anonymous, 2020). In India, Maharashtra state has highest average (42 lakh ha). Although, productivity in the state is very low $\left(334 \mathrm{~kg}\right.$ lint $\left.\mathrm{ha}^{-1}\right)$ as compared to national (501 kg lint $\mathrm{ha}^{-1}$ ). Weather aberrations, dominance of rainfed area and cultivation of cotton in shallow and light soils are some of the major reasons for low productivity in central zone. Further, 
cotton hybrids are predominantly cultivated in India and high cost of $B t$ cotton hybrid seeds is also one of the reasons for farmers indebtness during recurrent crop failure. For improving the productivity and profitability in this region, it necessitates a system which should be alternative for these reasons to the existing $B t$ cotton hybrid cultivation.

High density planting system (HDPS) leads to rapid canopy closing leading to reduced soil water evaporation. Better genotypes which are suitable for HDPS is an option to increase productivity in rainfed cotton with shallow to medium soils. Early maturity in shallow to medium soils doesn't support excessive vegetative growth leading to make high density planting system suitable for upland shallow to medium soils. Genotypes having adoptions in high density is most necessary for HDPS. Conventional and late maturing hybrids often experience terminal drought resulting in low yields (Jost and Cothren, 2001). One need compact, and early genotypes with synchronous boll opening and minimum monopodial branches for HDPS. Spatial arrangement of compact and short statured plants by agronomic manipulation of row spacing with increased plant density can obtain higher yield. There is better light interception, greater leaf area, low weed competition and earliness in crop maturity by adoption of ultra-narrow row cotton (Wright et al., 2011). Early maturity by adoption ultranarrow cotton can make this higher density planting system suitable to shallow to medium soils where. One needs compact and early genotypes with synchronous boll opening and minimum monopodial branches for HDPS. Spatial arrangement of compact and short statured plants by agronomic manipulation of row spacing with increased plant density can obtain higher yield. There is better light interception, greater leaf area, low weed competition and earliness in crop maturity by adoption of ultra-narrow row cotton (Wright et al., 2011). Selection of suitable genotypes and spacing i.e. plant population aim at improving the productivity. Present day cotton hybrids are tall growing, spreading type with long duration. Cultivation of hirsutum or arboreum cotton varieties may be an option to high seed cost which further can reduce production cost with low fertilizer requirement as compared to $B t$ cotton hybrids. Some of the recently released varieties are known for their tolerance to drought, sucking pests and diseases. Jagannathan and Venkitaswamy (1996) revealed that dwarf compact genotypes responded favourably to a population of $1,11,000$ plants $\mathrm{ha}^{-1}$ on Vertisols.

Hence an experiment was conducted to find out suitable hirsutum cotton genotype for high density planting system and identification of optimum plant density for those genotypes under high density planting system.

\section{Materials and Methods}

The field experiment was conducted at Cotton Research Station, Nanded (M.S.) during kharif seasons of year 2013-14 to 2015-16 under TMC MM I 1.4 project. The objectives were to evaluate performance of hirsutum genotypes under high density planting system with respect to yield and to identify optimum plant density for HDPS under rainfed condition. Nanded is located in Maharashtra state, India which lies in central cotton growing zone at $19.13^{\circ}$ North latitude and $77.34^{\circ}$ East longitude with an altitude of 362 $\mathrm{m}$ above mean sea level. The experiment was conducted with three replication and laid out in split plot design. The soil was medium black with low available nitrogen, medium available phosphorus and high potassium content with soil depth up to $75 \mathrm{~cm}$. The treatments were consisted of three plant densities in main plot viz., 2.22 lakh ha $^{-1}(45 \mathrm{x}$ $10 \mathrm{~cm}), 1.66$ lakh ha $^{-1}(60 \times 10 \mathrm{~cm})$ and 1.11 
lakh ha ${ }^{-1}(75 \times 10 \mathrm{~cm})$ with five hirsutum cotton varieties, NH 615, AKH 081, Suraj, NH 545 and NH 635 in sub plot. The crop was sown in $25^{\text {th }}, 29^{\text {th }}$ and $25^{\text {th }}$ MW during year 2013-14, year 2014-15 and year 201415 , respectively. Sowing was delayed in year 2014-15 due to late onset of monsoon. Surplus (52 per cent) rainfall was received during year 2013-14 (June to December) whereas, 46.3 and 37.75 per cent deficit rains over average rainfall were received during later two years. The crop was grown with other recommended package of practices under rainfed condition.

\section{Results and Discussion}

\section{Growth characters}

The effect of plant densities was not evident on mean plant height and number of sympodial branches plant $^{-1}$ (Table 1). Significant increase in monopodia plant ${ }^{-1}$ (0.79) was observed with lower plant density (1.11 lakh ha ${ }^{-1}$ ). Ajaykumar et al., (2017); Udikeri and Shashidhara (2017) also observed increase in number of monopodia plant ${ }^{-1}$ in wider row spacing. Only numerical increase in plant height and reduction in sympodial branches were observed due to increase plant density. All the genotypes exhibited almost similar mean plant height and didn't differed in number of branches plant ${ }^{-1}$.

\section{Yield attributes and seed cotton yield ha ${ }^{-1}$}

\section{Plant density}

The highest number of bolls $\mathrm{m}^{-2}$ were recorded in density 2.22 lakh/ha (91.00) which was at par with $1.66 \mathrm{lakh} / \mathrm{ha}$ (88.07). Ajaykumar et al., (2017) reported that maximum LAI in higher plant density utilized all natural resources like solar radiation, moisture, space and nutrients resulting in more photosynthesis leading to more number of bolls per unit area, which ultimately improved seed cotton yield. Udikeri and Shashidhara (2017) quoted more boll weight and light transmission in wider spacing whereas, more light absorption in closer spacing.

Mean yield plant ${ }^{-1}$ and boll weight were statistically similar for all the plant densities however, 1.66 lakh ha $^{-1}$ recorded higher numerical values (Table 1). Pradeep Kumar $e t$ al., (2017) also reported similar boll weight under different plant densities at Parbhani (MS) under HDPS. Better development of individual plants in wider rows couldn't compensate the yield on area basis.

The seed cotton yield for first year were higher as rains were received in September October months during boll development stage whereas, deficient rains along with early cessation observed in later two years resulted in low yields (Table 2). Based on pooled mean of three years, plant density of 1.66 lakh ha $^{-1}$ (spacing $60 \times 10 \mathrm{~cm}$ ) recorded highest seed cotton yield $\left(1705 \mathrm{~kg} \mathrm{ha}^{-1}\right)$ which was on par with density 2.22 lakh ha $^{-1}$ i.e. spacing 45 x $10 \mathrm{~cm}\left(1679 \mathrm{~kg} \mathrm{ha}^{-1}\right)$. Both higher plant densities (1.66 lakh and 2.22 lakh ha ${ }^{-1}$ ) recorded 14.50 and 12.76 per cent increase in seed cotton yield, respectively over lowest density (1.11 lakh ha $\left.{ }^{-1}\right)$ significantly. Although number of sympodial branches plant $^{-1}$, yield plant ${ }^{-1}$ and boll weight were not affected due plant densities, even though increase in number of plants per unit area could have compensated the decrease in yield plant $^{-1}$ under high density. This decrease in yield attributes might be caused due to over population of plants in unit area and more competition for light, air, nutrients and moisture (Udikeri and Shashidhara, 2017). Khargkharate et al., (2017) also reported significant yield in $60 \times 10 \mathrm{~cm}$ spacing $(1.66$ lakh plants $\mathrm{ha}^{-1}$ ) over conventional at Akola (MS). 
The narrow row spacing might have allowed more interception of light which has translated in yield. Optimum plant density has parabolic relationship with yield which was a function of the genotype, soil type, climate and management (Venugopalan et al., 2013). Increase in yield in HDPS was also reported by Arunvenkatesh and Rajendran (2013);
Paslawar et al., (2015); Pradeep Kumar et al., (2017); Nalayini and Manickam (2018). The plant density didn't affect the ginning outturn during all the years and on pooled mean basis (Table 2). Similar results were also reported by Arunvenkatesh and Rajendran (2013); Nalayini and Manickam (2018).

Table.1 Mean plant growth and yield contributing characters as influenced by plant densities and genotypes

\begin{tabular}{|c|c|c|c|c|c|c|}
\hline Treatment & $\begin{array}{c}\text { Plant } \\
\text { height } \\
\text { (cm) }\end{array}$ & $\begin{array}{l}\text { Mono- } \\
\text { podia }^{-1} \\
\text { plant }^{-1}\end{array}$ & $\begin{array}{c}\text { Sympodia } \\
\text { plant }^{-1}\end{array}$ & $\begin{array}{l}\text { Yield } \\
\text { plant }^{-1} \\
\text { (g) }\end{array}$ & $\begin{array}{l}\text { No. of } \\
\text { Bolls } \\
\mathbf{m}^{-2}\end{array}$ & $\begin{array}{c}\text { Boll } \\
\text { weight } \\
\text { (g) }\end{array}$ \\
\hline \multicolumn{7}{|l|}{ Plant density (D) } \\
\hline $\begin{array}{l}D_{1}: 2.22 \text { lakh ha }{ }^{-1}(45 \times 10 \\
\text { cm) }\end{array}$ & 76.33 & 0.55 & 9.00 & 8.61 & 91.00 & 1.81 \\
\hline $\begin{array}{l}D_{2}: 1.66 \text { lakh ha }{ }^{-1}(60 \times 10 \\
\text { cm) }\end{array}$ & 75.96 & 0.66 & 9.85 & 10.75 & 88.07 & 1.93 \\
\hline $\begin{array}{l}D_{3}: 1.11 \text { lakh ha }{ }^{-1}(75 \times 10 \\
\text { cm) }\end{array}$ & 74.59 & 0.79 & 10.29 & 12.48 & 76.98 & 2.01 \\
\hline $\mathrm{SE}_{ \pm}$ & 1.01 & 0.02 & 0.34 & 0.92 & 3.26 & 0.06 \\
\hline CD at 5\% & N.S. & 0.05 & N.S. & N.S. & 9.43 & N.S. \\
\hline \multicolumn{7}{|l|}{ Genotypes (G) } \\
\hline$G_{1}:$ NH 615 & 75.04 & 0.62 & 10.02 & 11.47 & 92.12 & 1.97 \\
\hline$G_{2}:$ AKH 081 & 73.55 & 0.71 & 9.66 & 10.21 & 80.39 & 1.89 \\
\hline $\mathbf{G}_{3}:$ Suraj & 77.59 & 0.68 & 9.50 & 9.24 & 72.95 & 2.03 \\
\hline $\mathrm{G}_{4}: \mathrm{NH} 545$ & 75.37 & 0.64 & 9.60 & 10.76 & 90.37 & 1.87 \\
\hline$G_{5}:$ NH 635 & 76.59 & 0.66 & 9.78 & 11.39 & 90.93 & 1.83 \\
\hline $\mathbf{S E}_{ \pm}$ & 1.46 & 0.03 & 0.24 & 0.51 & 3.40 & 0.06 \\
\hline CD at $5 \%$ & N.S. & N.S. & N.S. & 1.47 & 9.83 & N.S. \\
\hline \multicolumn{7}{|l|}{ Interaction D x G } \\
\hline $\mathrm{SE}_{ \pm}$ & 2.54 & 0.05 & 0.42 & 0.88 & 5.89 & 0.11 \\
\hline CD at $5 \%$ & N.S. & N.S. & N.S. & N.S. & N.S. & N.S. \\
\hline GM & 75.63 & 0.66 & 9.71 & 10.61 & 85.35 & 1.92 \\
\hline
\end{tabular}


Table.2 Seed cotton yield $\left(\mathrm{kg} \mathrm{ha}^{-1}\right)$ as influenced by plant densities and genotypes

\begin{tabular}{|c|c|c|c|c|c|}
\hline \multirow[t]{2}{*}{ Treatment } & \multicolumn{4}{|c|}{ Seed cotton yield $\left(\mathrm{kg} \mathrm{ha}^{-1}\right)$} & \multirow{2}{*}{$\begin{array}{c}\text { Ginning } \\
\text { out turn } \\
(\%)\end{array}$} \\
\hline & 2013-14 & 2014-15 & 2015-16 & $\begin{array}{l}\text { Pooled } \\
\text { Mean }\end{array}$ & \\
\hline \multicolumn{6}{|l|}{ Plant density (D) } \\
\hline $\begin{array}{l}D_{1}: 2.22 \text { lakh ha }^{-1}(45 \times 10 \\
\text { cm) }\end{array}$ & 2553 & 1287 & 1196 & 1679 & 36.06 \\
\hline $\begin{array}{l}D_{2}: 1.66 \text { lakh ha }^{-1}(60 \times 10 \\
\text { cm) }\end{array}$ & 2674 & 1282 & 1157 & 1705 & 36.14 \\
\hline $\begin{array}{l}D_{3}: 1.11 \text { lakh ha }^{-1}(75 \times 10 \\
\text { cm) }\end{array}$ & 2359 & 1062 & 1047 & 1489 & 36.40 \\
\hline $\mathrm{SE}_{ \pm}$ & 104.35 & 34.97 & 31.54 & 32.65 & 0.18 \\
\hline CD at $5 \%$ & 304.12 & 101.91 & 91.92 & 94.41 & N.S. \\
\hline \multicolumn{6}{|l|}{ Genotypes (G) } \\
\hline$G_{1}:$ NH 615 & 2747 & 1254 & 1225 & 1742 & 37.35 \\
\hline $\mathbf{G}_{2}: \mathbf{A K H ~} 081$ & 2347 & 1117 & 1080 & 1515 & 35.13 \\
\hline $\mathbf{G}_{3}:$ Suraj & 2588 & 1260 & 1026 & 1625 & 37.40 \\
\hline$G_{4}:$ NH 545 & 2403 & 1218 & 1048 & 1556 & 36.07 \\
\hline$G_{5}:$ NH 635 & 2558 & 1203 & 1289 & 1683 & 35.16 \\
\hline $\mathrm{SE}_{ \pm}$ & 69.86 & 44.02 & 29.94 & 33.76 & 0.27 \\
\hline CD at $5 \%$ & 203.59 & 128.30 & 87.26 & 97.63 & 0.73 \\
\hline \multicolumn{6}{|l|}{ Interaction D x G } \\
\hline $\mathrm{SE}_{ \pm}$ & 121.00 & 76.24 & 51.86 & 58.48 & 0.46 \\
\hline CD at $5 \%$ & 352.64 & 222.22 & N.S. & N.S. & 1.27 \\
\hline GM & 2529 & 1210 & 1133 & 1624 & 36.22 \\
\hline
\end{tabular}


Table.3 Economics of plant densities and genotypes under HDPS (pooled mean)

\begin{tabular}{|c|c|c|c|}
\hline Treatment & GMR (Rs. /ha) & NMR (Rs. /ha) & $B: C$ ratio \\
\hline \multicolumn{4}{|l|}{ Plant density (D) } \\
\hline $\begin{array}{l}D_{1}: 2.22 \text { lakh ha }{ }^{-1}(45 \times 10 \\
\text { cm) }\end{array}$ & 77083 & 38294 & 1.95 \\
\hline $\begin{array}{l}D_{2}: 1.66 \text { lakh ha }{ }^{-1}(60 \times 10 \\
\text { cm) }\end{array}$ & 78468 & 40496 & 2.01 \\
\hline $\begin{array}{l}D_{3}: 1.11 \text { lakh ha }^{-1}(75 \times 10 \\
\text { cm) }\end{array}$ & 68689 & 32472 & 1.85 \\
\hline SE \pm & 1666 & 1517 & - \\
\hline CD at $5 \%$ & 4818 & 4387 & - \\
\hline \multicolumn{4}{|l|}{ Genotypes (G) } \\
\hline $\mathbf{G}_{1}:$ NH 615 & 80292 & 41926 & 2.03 \\
\hline $\mathrm{G}_{2}: \mathrm{AKH} 081$ & 69704 & 32701 & 1.84 \\
\hline $\mathbf{G}_{3}:$ Suraj & 74825 & 37161 & 1.95 \\
\hline $\mathbf{G}_{4}:$ NH 545 & 71505 & 34253 & 1.88 \\
\hline$G_{5}:$ NH 635 & 77409 & 39395 & 1.99 \\
\hline $\mathrm{SE}_{ \pm}$ & 1601 & 1401 & - \\
\hline CD at $5 \%$ & 4631 & 4051 & - \\
\hline \multicolumn{4}{|l|}{ Interaction D x V } \\
\hline SE士 & 2774 & 4226 & - \\
\hline CD at $5 \%$ & N.S. & N.S. & - \\
\hline GM & 74747 & 37088 & 1.94 \\
\hline
\end{tabular}

\section{Genotypes}

The genotype NH 615 recorded highest mean yield plant $^{-1}(11.47 \mathrm{~g})$, bolls $\mathrm{m}^{-2}$ (92.12) and seed cotton yield $\left(1742 \mathrm{~kg} \mathrm{ha}^{-1}\right)$. It was found on par with NH $635\left(1683 \mathrm{~kg} \mathrm{ha}^{-1}\right)$. Seed cotton yield $\mathrm{ha}^{-1}$ is the product of number of bolls per unit area and individual boll weight. Genotypes NH 615, NH 635 and Suraj were found significantly superior over AKH 081. These results are in conformity with best performance of genotype $\mathrm{NH} 615$ under HDPS at Akola, Nanded, Nagpur and
Nandyal under rainfed condition whereas, average performance of Suraj at thirteen locations was better during 2010-11 (AICCIP, 2012). The genotypes had significant variations in ginning out turn (Table 2). Genotype Suraj recorded highest mean GOT $(37.40 \%)$ followed by NH $615(37.35 \%)$.

\section{Economics}

Highest mean GMR (Rs. 78,468/- ha $^{-1}$ ), NMR (Rs. 40,496/- ha ${ }^{-1}$ ) and B:C ratio (2.01) were obtained from plant density 1.66 lakh plants 
ha $^{-1}$ (geometry $60 \times 10 \mathrm{~cm}$ ). Increase in NMR by 24.71 per cent and 17.93 per cent, respectively was received by adopting high density of 1.66 lakh and 2.2 lakh plants ha ${ }^{-1}$ over 1.11 lakh ha ${ }^{-1}$ (Table 3). More monetary returns from higher density were also reported by Paslawar et al., (2015); Khargkharate et al., (2017); Pradeep Kumar (2017); Udikeri and Shashidhara, (2017).

Increase in seed cotton yield $\mathrm{ha}^{-1}$ has depicted in increased monetary values of genotypes. Genotype NH 615 recorded highest mean monetary values (GMR- Rs. 80,292/- ha ${ }^{-1}$, NMR - Rs. 41,926/- ha ${ }^{-1}$ and B:C ratio 2.03).

In conclusion, cotton yields on medium to shallow soils can be increased by high density planting system. Spacing $60 \times 10 \mathrm{~cm}$ (plant density of 1.66 lakhs plants ha $^{-1}$ ) is optimum for HDPS of hirsutum cotton genotypes on medium soil type. Hirsutum varieties NH 615, NH 635 and Suraj were found suitable for higher seed cotton yield under HDPS.

\section{Acknowledgement}

The financial support provided by the ICAR CICR, Nagpur under the Technology Mission on Cotton MM I 1.4 project for carrying out this research work is gratefully acknowledged.

\section{References}

AICCIP. 2012. - AICCIP Annual report 2011-2012, All India Coordinated Cotton Improvement Project, Coimbatore, Tamilnadu- 641003.

Anonymous. 2020. Cotton - area, production and yield. Textile Commissioner of India. $\quad$ Retrieved from http://txcindia.gov.in/

Ajayakumar, M. Y., Umesh, M. R., Shivaleela and Nidagundi, J.M. 2017. Light interception and yield response of cotton varieties to high density planting and fertilizers in sub-tropical India. $J$. Applied and Natural Sci. 9 (3): 1835 1839.

Arunvenkatesh, S. and Rajendran, K. 2013. Evaluation of plant density and cotton genotypes (Gossypium hirsutum L.) on cotton yield and fibre quality. Internat. J. Forestry \& Crop Improv. 4 (1): 1-5.

Jagannathan, N.T. and Venkitaswamy, R. 1996. Effect of plant density and nutrient levels of new cotton varieties. Madras Agric. J., 83 (3): 159-161.

Jost, P.H., and Cothren, J.T. 2001. Phenotypic alterations and crop maturity differences in ultra-narrow row and conventionally spaced cotton. Crop Science. 41:11501159.

Khargkharate, V.K., Ghanbahadur, M., Hiwale, S., Chirde, P. and Shaikh, S.A. 2017. Effect of high density planting, nutrient management and moisture conservation on economics and nutrient uptake of hirsutum cotton under rainfed condition. Int. J. Pure App. Biosci. 5 (6): 1210-1217.

Nalayini, P. and Manickam, S. 2018. Agronomic manipulation of high strength cotton genotype, $\mathrm{CCH} 4474$ for yield maximization under irrigated agro-ecosystem of Coimbatore. J. Cotton Res. Dev. 32 (2): 256-259.

Paslawar, A. N., Deotalu, A. S. and Nemade, P. W. 2015. High Density Planting System of cotton variety AKH - 081 under rainfed condition of Vidarbha. Plant Archives. 15 (2): 1075-1077.

Pradeep Kumar, Karle, A.S., Singh, Deshraj and Verma, Lalita. 2017. Effect of High Density Planting System (HDPS) and Varieties on Yield, Economics and Quality of Desi Cotton. Int. J. Curr. Microbiol. App. Sci. 6 (3): 233-238

Udikeri, Manjula and Shashidhara, G. B. 2017. Performance of compact cotton genotypes under high density planting 
system at different fertilizer levels. $J$. Farm Sci., 30 (4): 460-466.

Venugopalan, M.V., Kranthi, K.R., Blaise, D., Lakde, Shubhangi and Shankaranarayanan, K. 2013. High density planting system in cotton-The Brazil Experience and Indian Initiatives.
Cotton Res. J. 5 (2): 172-185. Wright, D. L., Marois, J. J., Sprenkel, R. K. and Rich J. R. 2011 - Production of Ultra Narrow Row Cotton. University of Florida (UF), IFAS Extension. SSAGR-83.

\section{How to cite this article:}

Pandagale, A. D., K. S. Baig, S. S. Rathod and Namade, T. B. 2020. Plant Density and Genotype Evaluation for High Density Planting System of Cotton under Rainfed Condition. Int.J.Curr.Microbiol.App.Sci. 9(09): 1291-1298. doi: https://doi.org/10.20546/ijcmas.2020.909.158 